\title{
ВИКОРИСТАННЯ КОМПОНЕНТНОЇ МЕТОДОЛОГІї РЕІНЖИНІРИНГУ БІЗНЕС-ПРОЦЕСІВ В ОСВІТІ
}

За останні роки в закордонних системах освіти багатьох країн відбулися суттєві структурні зміни, зумовлені розвитком науково-технічного прогресу та його зростаючим впливом на всі області життя суспільства. Одна з причин зміни підходу до організації освіти полягає в тому, що стрімкий розвиток нових інформаційних технологій сприяв появі в усьому світі великої кількості програмних продуктів, орієнтованих на використання в освітніх цілях. Інша причина пов'язана із зростаючою потребою сучасного інформаційного суспільства в кваліфікованих спеціалістах.

Традиційні методи і форми навчання сьогодні вже не можуть повністю задовольнити потребу в послугах навчання всіх категорій населення. На Україні існує гостра потреба в масовій підготовці та перепідготовці кадрів. Спостерігається нестача кваліфікованих інженерів, менеджерів, а також загальна комп'ютерна неграмотність персоналу різних сфер діяльності. Тому на сучасному етапі розвитку науки і техніки у всіх фрормах вищої, середньої та професійної освіти актуальним стає дистанційне навчання, яке базуеться на основі використання технологій віддаленого доступу до інформаційних ресурсів і знань, що включає мережну комп’ютерну взаємодію студентів з викладачами і між собою, використання електронних курсів та навчальних середовищ, мережне тестування, пошук різних джерел знань в Інтернеті.

На теперішній час для впровадження та використання дистанційного навчання всі принципові технічні проблеми вирішені. Якість такого навчання буде визначатися якістю навчальних програм, кваліфікацією викладачів та організацією учбового процесу. Найважливішою вимогою до системи дистанційного навчання є забезпечення його індивідуальності, тобто навчання кожного конкретного студента у відповідності з його особливостями та задачами.

Впровадження технологій дистанційного навчання в освітні процеси суттєво змінює їх організацію, передбачаючи необхідність реінжинірингу сукупності взаємопов'язаних бізнес-процесів освітніх закладів.

Основу компонентного конфігурування процесу (сценарію) навчання у віртуальному освітньому середовищі складає створення та використання інтегрованого простору знань (ІПЗ), що об'єднуе знання суміжних наукових дисциплін на основі принципів побудови систем управління знаннями.

Компонентна технологія конфігурування навчальних процесів на основі інтегрованого простору знань дозволяє, з одного боку, скоротити затрати та покращити якість розробки навчально-методичного забезпе-

(c) Т.В. Лошак, С.В. Крилов, В.К. Анікін, 2004 
чення, а з іншого боку, підвищити ефективність безпосередньо навчального процесу.

Економію затрат при створенні та підтримці учбово-методичного забезпечення відкритої освіти в результаті використання компонентної технології можна виразити фрормулою [1]:

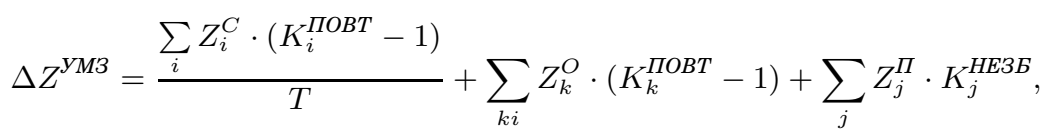

де $\Delta Z^{y M 3}$ - економія затрат при створенні інтегрованого простору знань порівняно з традиційними електронними курсами;

$Z_{i}^{C}$ - затрати на створення $i$-го об'єкта;

$Z_{k}^{O}$ - затрати на оновлення $k$-го об'єкта;

$Z_{j}^{\Pi}$ - затрати на пошук відсутнього $j$-го об'єкта;

$T$ - число років функціонування об'єкта;

$K_{k}^{\Pi O B T} \geqslant 1$ - коефіцієнт повторюваності об'єкта в курсах;

$K_{j}^{H E 3 Б}$ — коефіцієнт незабезпеченості об'єкта в курсах (1 або 0).

Економія затрат на навчання при компонентній технології конфрігурування сценарію навчання обчислюеться за формулою:

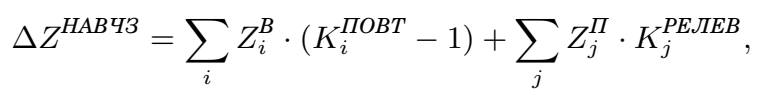

де $Z_{i}^{B}$ - затрати на вивчення $i$-го об'єкта;

$Z_{j}^{\Pi}$ — затрати на пошук та вивчення додаткового $j$-го об'єкта;

$K_{i}^{\Pi O B T} \geqslant 1$ - коефіцієнт повторюваності об'єкта в курсах;

$K_{j}^{P E л E B}$ - зміна коефіцієнта релевантності відбору додаткових об'єктів.

Після того як спроектована нова організація бізнес-процесів, можна точно визначити затрати на їх експлуатацію з урахуванням запланованих об'ємів робіт, отже, і розрахувати одержані економічні результати від їх реінжинірингу.

Для визначення об'ємів робіт бізнес-плану пропонуеться побудувати економіко-математичну модель, що максимізує сукупний прибуток підприємства за всіма видами діяльності при обмеженнях на об'єми виконуючих процеси ресурсів та об’єми фрінансування. Цільова функція зводиться до максимізації сукупного прибутку за всіма категоріями студентів при оптимальному розподілі об'ємів прийому на платне навчання в системі відкритої освіти за категоріями студентів.

$$
M=\sum_{i} V_{i} \sum_{j}\left(P_{i j}-C_{i j}\right) \rightarrow \max
$$

де $M$ - сукупний прибуток освітнього закладу;

$P_{i j}$ — ціна одиниці $j$-го курсу по $i$-ій категорії студентів. У випадку отримання вищої освіти приймемо ціни будь-яких курсів $i$-ої категорії студентів рівним та залежними від ціни освіти $\left(P_{i}\right)$ та числа курсів по $i$-ій категорії студентів $\left(q_{i}\right)$, тобто 


$$
P_{i j}=\frac{P_{i}}{q_{i}}
$$

$C_{i j}$ - собівартість навчання одного студента $i$-ій категорії по $j$-му курсу; $V_{i}$ - число студентів $i$-ої категорії за розглянути період часу (найчастіше рік).

В якості ресурсного обмеження приймемо можливості викладачів по здійсненню навчання протягом заданого періоду часу (комп'ютерні і телекомунікаційні ресурси будемо вважати необмеженими в частині обслуговування потреб студентів). Тоді обмеження на пропускну здатність викладачів буде мати наступний вигляд:

$$
\sum_{i} V_{i} \cdot q_{i} \leqslant \sum_{i} \sum_{j} N_{i j} \cdot \nu_{i j}
$$

де $N_{i j}$ - число викладачів $j$-го курсу по $i$-ій категорії студентів; $\nu_{i j}$ нормативне число $i$-ої категорії студентів по $j$-му курсу на одного викладача за розглянутий період часу (найчастіше рік); $q_{i}-$ число курсів для $i$-ої категорії студентів.

Дистанційне навчання відрізняеться від традиційних форм високою динамічністю, пов'язаною з гнучкістю вибору студентами учбових курсів, великим об'ємом самостійної роботи, різновидом форм учбовометодичного забезпечення, що дає можливість різко підвищити ефективність освітніх процесів. Структурна модель процесу дистанційного навчання, виконана за допомогою засобу моделювання та аналізу бізнеспроцесів BPwin, представлена на рис. 1, 2.

BPwin пропонуеться для використання як засіб, що дозволяе полегшити проведення обстеження дистанційного навчання, побудувати функціональні моделі й надалі з їхньою допомогою проаналізувати й поліпшити бізнес-процеси.

Профресійна освіта ведучих країн світу побудована на використанні кредитних систем оцінки освітніх програм. Кредитно-залікові системи, як правило, виходять з поняття та визначення кредиту як одиниці оцінки працезатрат на освоєння освітньої програми або їі частини. Кредитнонакопичувальні системи, в основному визначають кредит як одиницю оцінки результатів освоєння освітніх програм - придбаних знань, здібностей та навичок.

Освітня програма навчання в сучасному вищому учбовому закладі складається із семестрових модулів (курсів, дисциплін) і оцінюеться кредитами. Кількість кредитів освітньої програми представляе собою суму кредитів окремих модулів (курсів, дисциплін) [4]:

$$
K=\sum_{n=1}^{N} k_{n}
$$

де $k_{n}$ - кількість кредитів, що відповідає $n-$ модулю і визначається 3 урахуванням основних принципів побудови кредитної системи. 
"ACAY" - 7(27) 2004

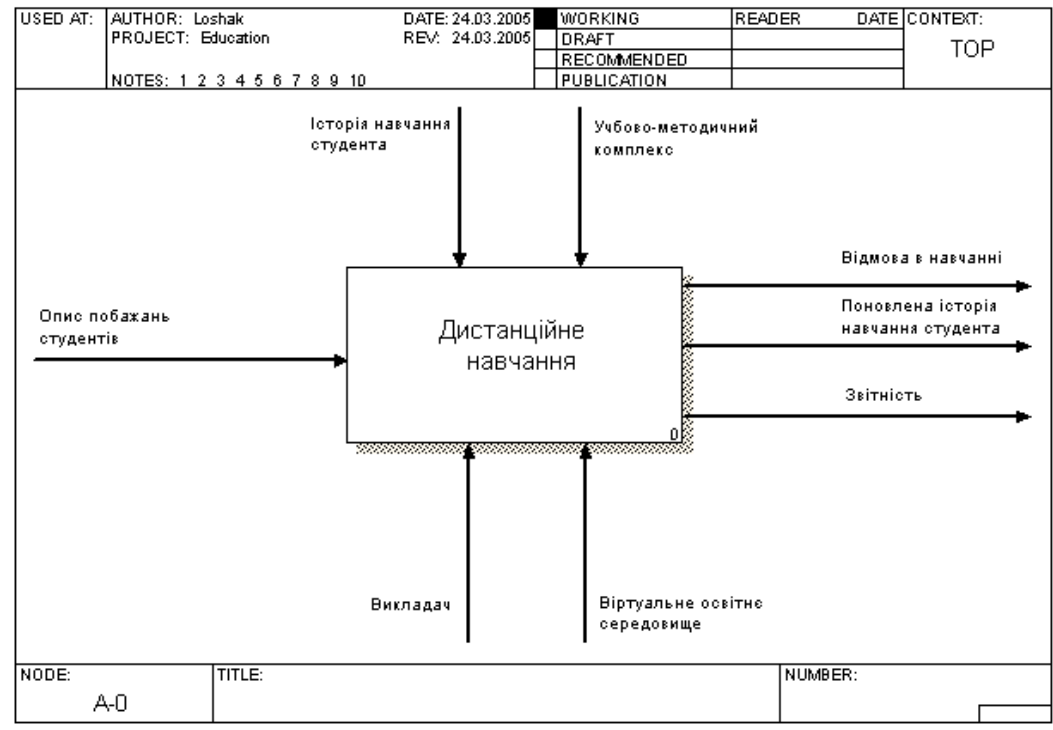

Рис. 1 - Опис процесу дистанційного навчання

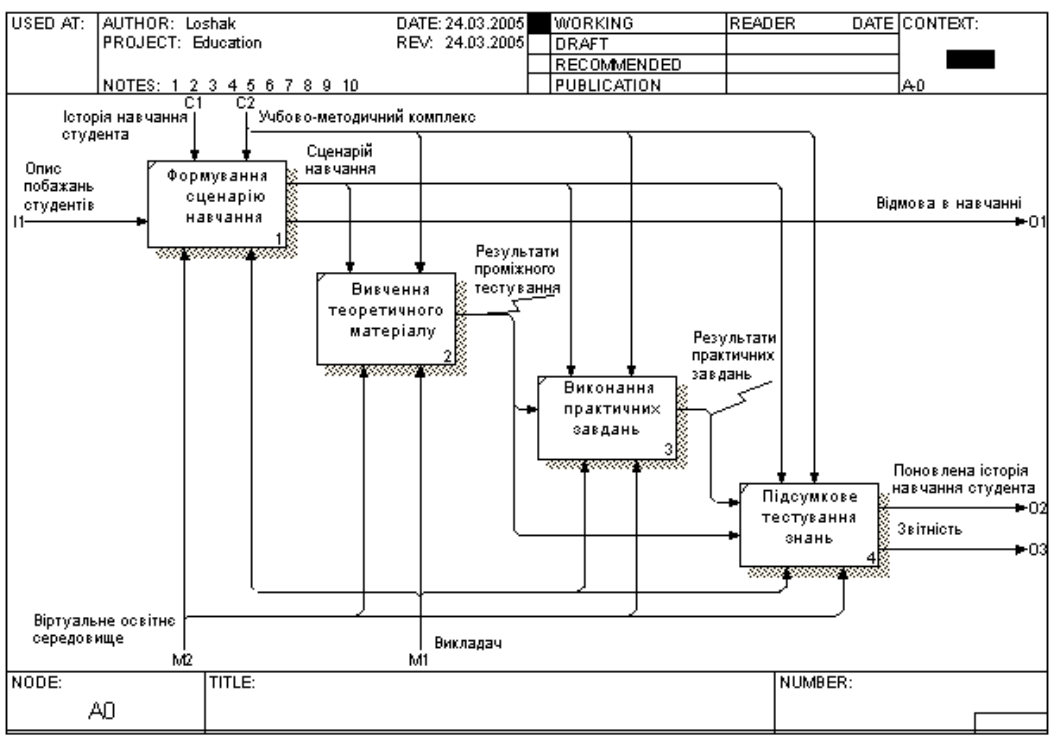

Рис. 2 - Схема процесу дистанційного навчання 
Максимальний рейтинг якості освоєння кожного модуля освітньої програми прийнятий $g_{i}=100$. Таким чином, фрактичний результат освоєння освітньої програми визначаеться у вигляді:

$$
R=0.01 \sum_{i=1}^{N} k_{i} g_{i}, \quad(R \leqslant K),
$$

а середній результуючий рейтинг студента залежить від відношення фрактичного результату освоєння освітньої програми до запланованого у відповідності з кредитною системою:

$$
G=\frac{R}{K}
$$

Кредитні системи, засновані на оцінці запланованих результатів освоєння освітніх програм, легко адаптуються до нових форм і технологій освітнього процесу, таких як дистанційне навчання, використання комп'ютерних та Internet- технологій.

\section{Література}

1. Тельнов Ю.Ф. Реинжиниринг бизнес-процессов. Компонентная методология. - 2-е изд., перераб. и доп. - М.: Финансы и статистика, 2004. - 320 с.: ил.

2. Ойхман Е.Г., Попов Э.В. Реинжиниринг бизнеса: Реинжиниринг организаций и информационные технологии. - М.: Финансы и статистика, 1997. - 336 с.: ил.

3. Нарожный А.В. Проектирование и реализация автоматизированных систем контроля знаний. // Автоматика. Автоматизация. Электротехнические комплексы и системы. - 2004. - 2 (14). - С.146154.

4. Яковенко А.Е. Проектирование автоматизированных систем принятия решений в условиях адаптивного обучения с учетом требований Болонского процесса. // Автоматика. Автоматизация. Электротехнические комплексы и системы. - 2004. - 2 (14). - С.159-168. 